\title{
EDUKASI BIJAK DALAM MEMILIH DAN MENGGUNAKAN SUPLEMEN PADA MASA PANDEMI COVID-19
}

\author{
Baiq Nurbaety'), Cyntiya Rahmawati'1), Baiq Leny Nopitasari²), Nurul Qiyaam²), \\ Alvi Kusuma Wardani'2), Anna Pradiningsih'2), Abdul Rahman Wahid") \\ 1)Program Studi D3 Farmasi, Fakultas Ilmu Kesehatan, Universitas Muhammadiyah Mataram, Mataram, \\ Nusa Tenggara Barat, Indonesia \\ 2)Program Studi S1 Farmasi, Fakultas IImu Kesehatan, Universitas Muhammadiyah Mataram, Mataram, \\ Nusa Tenggara Barat, Indonesia \\ Corresponding author : Baiq Nurbaety \\ E-mail : bq.tyee@gmail.com
}

Diterima 10 April 2021, Direvisi 25 April 2021, Disetujui 25 April 2021

\begin{abstract}
ABSTRAK
Novel coronavirus (COVID-19) saat ini telah menjadi pandemi dan masalah kesehatan dunia sehingga diperlukan upaya pengendalian dan pencegahan COVID-19. Salah satu upaya pencegahan yang dapat dilakukan adalah dengan meningkatkan ketahanan masyarakat, melalui kesehatan tubuh perorangan. Informasi mengenai suplemen kesehatan sangat diperlukan agar masyarakat dapat memilih dan menggunakan suplemen secara bijak untuk menghadapi COVID-19. Edukasi terkait penggunanaan suplemen kesehatan bertujuan untuk memberikan informasi yang benar, objektif dan tidak menyesatkan untuk menghadapi COVID-19 sehingga masyarakat dapat lebih memahaminya. Metode yang dilakukakan dengan memberikan sebanyak 30 booklet dan suplemen kesehatan kepada warga masyarakat Singasari, Puyung, Lombok Tengah. Wawasan masyarakat tentang penggunaan suplemen kesehatan meningkat setelah pemberian edukasi yang ditandai dengan masyarakat mampu mengulang kembali informasi yang sudah diberikan. Masyarakat dapat mengetahui bagaimana cara penggunaan suplemen yang tepat sehingga tidak salah dalam mengkonsumsi produk suplemen yang beredar dipasaran.
\end{abstract}

Kata kunci: covid-19; booklet; suplemen

\begin{abstract}
The novel coronavirus (COVID-19) has now become a pandemic and a world health problem, so efforts to control and prevent COVID-19 are needed. One of the preventive efforts that can be done is to increase community resilience through the health of the individual body. Information about health supplements is needed so that people can choose and use supplements wisely to deal with COVID-19. Education related to the use of health supplements aims to provide correct, objective and not misleading information to deal with COVID-19 so that the public can better understand it. The method is carried out by providing as many as 30 booklets and health supplements to residents of the Singasari community, Puyung, Central Lombok. Public awareness about the use of health supplements increased after the provision of education, which was marked by the community being able to repeat the information that had been given. The public can find out how to use the right supplement so that there is no mistake in consuming supplement products on the market.
\end{abstract}

Keywords: covid-19; booklet; supplement

\section{PENDAHULUAN}

Novel coronavirus (COVID-19) saat ini telah menjadi pandemic dan menjadi masalah kesehatan dunia. Kasus COVID-19, diawali dengan informasi dari Badan Kesehatan Dunia/World Health Organization (WHO) pada tanggal 31 Desember 2019 yang menyebutkan adanya kasus kluster pneumonia dengan etiologi yang tidak jelas di Kota Wuhan, Provinsi Hubei, China. Kasus ini terus berkembang hingga akhirnya diketahui bahwa penyebab kluster pneumonia ini adalah novel coronavirus.
(Perhimpunan Dokter Paru Indonesia, 2020)Kasus ini terus berkembang hingga adanya laporan kematian dan terjadi importasi di luar China (World Health Organization, 2020).

Pada tanggal 30 Januari 2020, WHO menetapkan COVID-19 sebagai Public Health Emergency of International Concern (PHEIC)/ Kedaruratan Kesehatan Masyarakat yang Meresahkan Dunia (KKMMD). Pada tanggal 12 Februari 2020, WHO resmi menetapkan penyakit novel coronavirus pada manusia ini dengan sebutan Coronavirus Disease (COVID- 
19 (Wikipedia, 2020). Kementerian Kesehatan Republik Indonesia telah menerbitkan panduan kepada masyarakat dalam menghadapi COVID-19 (Kemenkes RI, 2020)

Sampai dengan tanggal 28 Januari 2021, dilaporkan di Indonesia total kasus konfirmasi positif 1.037.993, sembuh 842.122 dan meninggal 29.331 orang (Kawal COVID19, 2021). Kasus COVID-19 di Indonesia tersebar di 30 Provinsi, termasuk Provinsi Nusa Tenggara Barat (NTB). Menurut data COVID19 di Provinsi NTB sampai pada tanggal 28 Januari 2021, jumlah pasien positif sebanyak 7.416 orang, dengan perincian 5.738 orang sudah sembuh, 328 meninggal dunia, serta 1.350 orang masih positif. Angka kejadian COVID-19 di Pulau Lombok yang tertinggi adalah Kota Mataram, Lombok Barat, Lombok Timur dan Lombok Tengah (COVID-19 NTB, 2020).

Menghadapi situasi seperti ini, maka diperlukan upaya pengendalian dan pencegahan COVID-19. Salah satu upaya pencegahan yang dapat dilakukan adalah dengan meningkatkan ketahanan masyarakat, melalui kesehatan tubuh perorangan. Daya tahan tubuh dapat dijaga dan ditingkatkan, utamanya melalui kebiasaan hidup sehat antara lain menjaga kebersihan, asupan nutrisi yang baik, ditambah dengan penggunaan suplemen kesehatan (Alodokter, 2020).

$$
\text { Pandemi COVID-19 membuat }
$$

sebagian besar masyarakat lebih sadar pentingnya menjaga kesehatan. Salah satu caranya dengan mengonsumsi obat herbal dan suplemen kesehatan untuk meningkatkan daya tahan tubuh agar terhindar dari serangan penyakit, termasuk COVID-19 (Badan Pengawas Obat dan Makanan Republik Indonesia, 2020). Vitamin dan suplemen sebaiknya dikonsumsi saat tubuh memang membutuhkan saja. Konsumsi vitamin dan suplemen yang tidak tepat dapat menyebabkan efek yang tidak diharapkan. Selain itu jika mengkonsumsi obat-obatan rutin, kemungkinan dapat menyebabkan interaksi obat (Andayani, 2020).

Berdasarkan pengamatan yang dilakukan di Lombok Tengah sendiri banyak masyarakat yang mengkonsumi suplemen untuk meningkatkan daya tahan tubuh agar terhindar dari serangan penyakit, termasuk COVID-19 terutama di Dusun Singasari, Puyung, Lombok Tengah. Banyaknya beredar suplemen yang diklaim mampu mencegah dan mengatasi COVID-19 beredar di kalangan masyaratakat. Diperlukan informasi mengenai suplemen kesehatan agar masyarakat dapat memilih dan menggunakan secara tepat dan bijak suplemen kesehatan untuk menghadapi
COVID-19. Oleh karena itu, perlu dilakukan edukasi terkait suplemen kesehatan dengan tujuan memberikan informasi yang benar, objektif dan tidak menyesatkan untuk menghadapi COVID-19 sehingga masyarakat dapat lebih memahaminya.

\section{METODE}

Pengabdian Kepada Masyarakat ini dilakukan di Dusun Singasari, Puyung Lombok Tengah pada tanggal 26 Maret 2021 dengan melibatkan Karang Taruna Singasari sebanyak 10 orang. Metode yang dilakukan pada pengabdian ini adalah melakukan penyuluhan tentang "Edukasi Bijak Dalam Memilih Dan Menggunakan Suplemen Pada Masa Pandemi Covid-19" melalui booklet yang dibagikan kepada warga masyarakat Singasari, Puyung, Lombok Tengah sebanyak 30 booklet. Booklet dibuat dengan mengadopsi dari Buku Saku Penggunaan Suplemen yang diterbitkan oleh BPOM kemudian dibagikan masyarakat disertai dengan pemberian informasi tentang penggunaan suplemen pada masa pandemi COVID-19. Selain memberikan booklet kepada masyarakat, kegiatan ini juga dilakukan dengan memberikan salah satu contoh suplemen yang bisa dikonsumsi oleh warga masyarakat Singasari, Puyung Lombok Tengah. Setelah pemberian informasi, mayarakat kemudian diberikan pertanyaan terkait pemahaman terhadapat penggunaan suplemen.

\section{HASIL DAN PEMBAHASAN}

Pneumonia COVID-19 adalah peradangan pada parenkim paru yang diduga disebabkan oleh SARS-CoV-2 (Perhimpunan Dokter Paru Indonesia, 2020). Virus ini sangat mudah menular melalui kontak perorangan secara langsung terutama pada orang yang memiliki imunitas rendah. Sejak penyebaran virus covid-19, banyak anjuran untuk mengonsumi suplemen atau vitamin untuk penambah daya tahan tubuh, seperti vitamin $C$ dan multivitamin yang mengandung zat besi, untuk mencegah penularan virus corona (Andayani, 2020).

Daya tahan tubuh merupakan dapat membantu melawan infeksi virus, salah satunya adalah virus penyebab COVID-19. Di kalangan masyarakat banyak beredar produk suplemen kesehatan sehingga masyarakat membutuhkan informasi yang dapat menjadi acuan untuk memelihara dan meningkatkan daya tahan tubuh serta kesehatan secara umum.

Pada kondisi tubuh yang baik, respon imun bekerja untuk mempertahankan kekebalan tubuh. Mengkonsumsi suplemen dapat sebagai penunjang agar imunitas tubuh 
tetap stabil, beberapa kandungan suplemen yang bermanfaat meningkatkan daya tahan tubuh (Puspensos, 2020). Namun, penggunaan tersebut tetap mempertimbangkan kondisi masing-masing individu sehingga diperlukan edukasi oleh tenaga kesehatan, khususnya Apoteker.

Suplemen bukan pengganti makanan sepenuhnya, kita tetap perlu mengonsumsi berbagai macam makanan sehat untuk memenuhi kebutuhan sehari-hari. Suplemen tidak seperti obat, suplemen tidak ditujukan untuk mengatasi, mendiagnosa, mencegah atau menyembuhkan penyakit. Beberapa suplemen mengandung bahan aktif yang memiliki efek biologik dalam tubuh, sehingga dapat membahayakan jika tidak digunakan secara tepat. Kombinasi suplemen, memberikan suplemen bersama obat, mengganti obat dengan suplemen atau menggunakan suplemen secara berlebihan adalah tindakan yang tidak tepat (Andayani, 2020).

Sejauh ini klaim khasiat/manfaat yang telah disetujui olah Badan POM RI masih sebatas membantu memelihara daya tahan tubuh. Belum pernah disetujui produk suplemen kesehatan dengan klaim mencegah atau mengobati penyakit yang disebabkan oleh virus COVID-19. Badan POM juga meluncurkan 10 produk informasi sebagai panduan bagi masyarakat salah satunya yaitu berupa Pedoman Penggunaan Herbal dan Suplemen Kesehatan dalam Menghadapi COVID-19 di Indonesia (Badan Pengawas Obat dan Makanan Republik Indonesia, 2020).

Kegiatan Pengabdian Kepada Masyarakat yang dilakukan berkerjasama dengan Karang Taruna Singasari, Puyung, Lombok Tengah. Kegiatan ini dilakukan untuk menambah wawasan masyarakat terhadap penggunaan suplemen. Penyuluhan ini bertujuan merubah perilaku masyarakat melalui penyebarluasan informasi, komunikasi, motivasi dan edukasi oleh penyuluh baik lisan maupun tulisan (Notoatmodjo, 2012).

Edukasi ini dilakukan dengan pemberian booklet yang berjumlah 30 booklet dimana setiap orang diberikan booklet mewakili setiap kepala keluarga. Pada saat pemberian booklet, masyarakat diberikan edukasi dan penjelasan singkat terkait dengan penggunaan suplemen sehingga pada saat pemberian edukasi tidak dilakukan dengan mengumpulkan masa dalam jumlah banyak untuk menghindari penyebaran virus Covid-19 karena masyarakat di Dusun Singasari, Puyung Lombok Tengah masih susah untuk menerapkan protokol kesehatan.

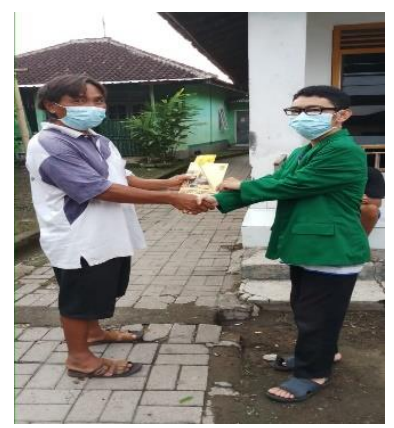

Gambar 1. Edukasi Penggunaan Suplemen

Selain pemberian edukasi melalui booklet, masyarakat juga diberikan salah satu contoh suplemen yang dapat dikonsumsi untuk meningkatkan daya tahan tubuh selama pandemi. Suplemen diberikan dengan jumlah 10 tablet untuk masing-masing Kepala Keluarga dengan aturan pakai yang sudah tertulis di kemasan suplemen yang diberikan.

Saat pemberian edukasi kepada masyarakat dapat dilihat bahwa masih banyak masyarakat yang kurang paham terhadap penggunaan suplemen yang beredar dipasaran. Beberapa masyarakat justru mengkonsumsi suplemen dengan merk dagang yang berbeda namun mengandung zat aktif yang sama. Namun, setelah pemberian edukasi kepada masyarakat akhirnya mereka memahami bahwa tidak semua suplemen tersebut harus mereka konsumsi secara bersama-sama. Masyarakat dapat memilih salah satu suplemen yang akan dikonsumsi dengan aturan pakai dan dalam kondisi yang tepat sehingga dapat mencegah efek yang tidak diharapkan. Diakhir kegiatan masyarakat diberikan kesempatan untuk menyampaikan kembali informasi yang sudah diberikan dan masyarakat dapat mengulang informasi yang sudah diberikan dengan tepat.

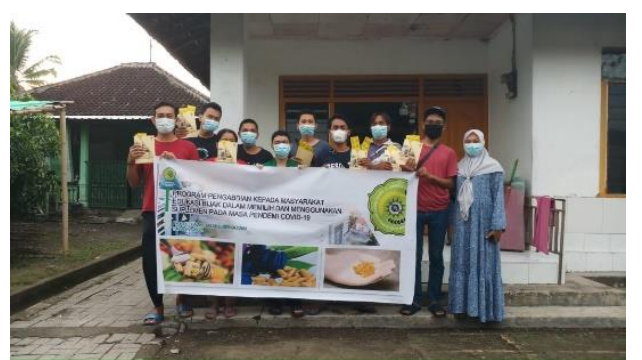

Gambar 2. Pembagian Booklet dan Suplemen

\section{SIMPULAN DAN SARAN \\ Simpulan}

Kegiatan Edukasi Bijak dalam Memilih dan Menggunakan Suplemen pada Masa Pandemi Covid-19 serta pembagian suplemen pada masyarakat Dusun Singasari, Puyung, Lombok Tengah telah dilakukan. Wawasan masyarakat 
tentang penggunaan suplemen kesehatan meningkat setelah pemberian edukasi yang ditandai dengan masyarakat mampu mengulang kembali informasi yang sudah diberikan. Masyarakat dapat mengetahui bagaimana cara penggunaan suplemen yang tepat sehingga tidak salah dalam mengkonsumsi produk suplemen yang beredar dipasaran. Booklet yang diberikan dapat digunakan sewaktu-waktu ketika masyarakat ingin mengulas kembali tentang suplemen yang akan digunakan.

\section{Saran}

Edukasi dapat dibuat dengan menyebarkan poster tentang suplemen kepada masyarakat agar dapat diletakkan di tempat umum serta pembagian booklet dan suplemen dapat diberikan kepada masyarakat yang lebih luas. Penerapan protokol kesehatan jga harus ditingkatkan.

\section{UCAPAN TERIMAKASIH}

Ucapan terimakasih diberikan kepada Lembaga Penelitian dan Pengabdian kepada Masyarakat (LPPM) Universitas Muhammadiyah Mataram yang telah mendanai kegiatan pengabdian ini sehingga kegiatan dapat berjalan dengan lancar. Terimkasih juga kepada semua tim pengabdian yang telah membantu dalam pelaksanaan kegiatan.

\section{DAFTAR RUJUKAN}

Alodokter (2020) Virus Corona - Gejala, Penyebab, dan Mengobati. Available at: https://www.alodokter.com/viruscorona (Accessed: 12 January 2021).

Andayani, T. M. (2020) Bijak Dalam Memilih dan Menggunakan Suplemen Pada Masa Pendemi Covid-19, Fakultas Farmasi UGM. Available at: https://farmasi.ugm.ac.id/id/bijakdalam-memilih-dan-menggunakansuplemen-pada-masa-pendemi-covid19/ (Accessed: 12 January 2021).

Badan Pengawas Obat dan Makanan Republik Indonesia (2020) Bijak Manfaatkan Obat Herbal dan Suplemen Kesehatan untuk Daya Tahan Tubuh Menghadapi Pandemi COVID-19. Available at: https://www.pom.go.id/new/view/more/ berita/18484/Bijak-Manfaatkan-ObatHerbal-dan-Suplemen-Kesehatanuntuk-Daya-Tahan-Tubuh-

Menghadapi-Pandemi-COVID-19.html (Accessed: 12 January 2021).

COVID-19 NTB (2020). Available at: https://corona.ntbprov.go.id/list-data (Accessed: 12 January 2021).

Kawal COVID19 (2021) Informasi Terkini COVID-19 di Indonesia. Available at: https://kawalcovid19.id/ (Accessed: 12 January 2021).

Kemenkes RI (2020) Infeksi Emerging Kementerian Kesehatan RI. Available at: https://covid19.kemkes.go.id/situasiinfeksi-emerging/situasi-terkiniperkembangan-novel-coronavirus2019-ncov-10-februari-2020/ (Accessed: 12 January 2021).

Notoatmodjo, S. (2012) Promosi kesehatan dan perilaku kesehatan. Jakarta: Rineka Cipta.

Perhimpunan Dokter Paru Indonesia (2020) Panduan Praktik Klinis: Pneumonia 2019-nCov. Jakarta: PDPI.

Puspensos (2020) Penyuluhan Melalui Media Sosial Tentang Pentingnya Optimalisasi Sistem Imunitas Tubuh: Guna memberantas COVID-19 dan $D B D$ di Indonesia. Available at: https://puspensos.kemensos.go.id/pen yuluhan-melalui-media-sosial-tentangpentingnya-optimalisasi-sistemimunitas-tubuh-guna-memberantascovid-19-dan-dbd-di-indonesia (Accessed: 12 January 2021).

Wikipedia (2020) Pandemi COVID-19 di Indonesia. Available at: https://id.wikipedia.org/wiki/Pandemi COVID-19_di_Indonesia (Accessed: 12 January 2021).

World Health Organization (2020) WHO Director-General's remarks at the media briefing on 2019-nCoV on 11 February 2020. Available at: https://www.who.int/directorgeneral/speeches/detail/who-directorgeneral-s-remarks-at-the-mediabriefing-on-2019-ncov-on-11-february2020 (Accessed: 12 January 2021). 